\title{
SARS-CoV-2 Wave Two Surveillance in East Asia and the Pacific: Longitudinal Trend Analysis
}

Lori Ann Post ${ }^{1}$, PhD; Jasmine S Lin², BA; Charles B Moss ${ }^{3}$, PhD; Robert Leo Murphy ${ }^{4}$, MD; Michael G Ison ${ }^{5}$, MD, MSc; Chad J Achenbach ${ }^{5}$, MD, MPH; Danielle Resnick ${ }^{6}$, PhD; Lauren Nadya Singh ${ }^{1}$, MPH; Janine White ${ }^{1}$, MA; Michael J Boctor ${ }^{2}$, BSc; Sarah B Welch ${ }^{1}$, MPH; James Francis Oehmke ${ }^{1}, \mathrm{PhD}$

\footnotetext{
${ }^{1}$ Buehler Center for Health Policy and Economics, Feinberg School of Medicine, Northwestern University, Chicago, IL, United States

${ }^{2}$ Feinburg School of Medicine, Northwestern University, Chicago, IL, United States

${ }^{3}$ Institute of Food and Agricultural Sciences, University of Florida, Gainsville, FL, United States

${ }^{4}$ Institute for Global Health, Feinberg School of Medicine, Northwestern University, Chicago, IL, United States

${ }^{5}$ Division of Infectious Disease, Feinberg School of Medicine, Northwestern University, Chicago, IL, United States

${ }^{6}$ International Food Policy Research Institute, Washington DC, DC, United States
}

\section{Corresponding Author:}

Lori Ann Post, PhD

Buehler Center for Health Policy and Economics

Feinberg School of Medicine

Northwestern University

420 E Superior St

Chicago, IL, 60611

United States

Phone: 12039807108

Email: lori.post@northwestern.edu

\section{Abstract}

Background: The COVID-19 pandemic has had a profound global impact on governments, health care systems, economies, and populations around the world. Within the East Asia and Pacific region, some countries have mitigated the spread of the novel coronavirus effectively and largely avoided severe negative consequences, while others still struggle with containment. As the second wave reaches East Asia and the Pacific, it becomes more evident that additional SARS-CoV-2 surveillance is needed to track recent shifts, rates of increase, and persistence associated with the pandemic.

Objective: The goal of this study is to provide advanced surveillance metrics for COVID-19 transmission that account for speed, acceleration, jerk, persistence, and weekly shifts, to better understand country risk for explosive growth and those countries who are managing the pandemic successfully. Existing surveillance coupled with our dynamic metrics of transmission will inform health policy to control the COVID-19 pandemic until an effective vaccine is developed. We provide novel indicators to measure disease transmission.

Methods: Using a longitudinal trend analysis study design, we extracted 330 days of COVID-19 data from public health registries. We used an empirical difference equation to measure the daily number of cases in East Asia and the Pacific as a function of the prior number of cases, the level of testing, and weekly shift variables based on a dynamic panel model that was estimated using the generalized method of moments approach by implementing the Arellano-Bond estimator in R.

Results: The standard surveillance metrics for Indonesia, the Philippines, and Myanmar were concerning as they had the largest new caseloads at 4301, 2588, and 1387, respectively. When looking at the acceleration of new COVID-19 infections, we found that French Polynesia, Malaysia, and the Philippines had rates at 3.17, 0.22, and 0.06 per 100,000. These three countries also ranked highest in terms of jerk at 15.45, 0.10, and 0.04, respectively.

Conclusions: Two of the most populous countries in East Asia and the Pacific, Indonesia and the Philippines, have alarming surveillance metrics. These two countries rank highest in new infections in the region. The highest rates of speed, acceleration, and positive upwards jerk belong to French Polynesia, Malaysia, and the Philippines, and may result in explosive growth. While all countries in East Asia and the Pacific need to be cautious about reopening their countries since outbreaks are likely to occur in the second wave of COVID-19, the country of greatest concern is the Philippines. Based on standard and enhanced surveillance, the Philippines has not gained control of the COVID-19 epidemic, which is particularly troubling because the country ranks 4th 
in population in the region. Without extreme and rigid social distancing, quarantines, hygiene, and masking to reverse trends, the Philippines will remain on the global top 5 list of worst COVID-19 outbreaks resulting in high morbidity and mortality. The second wave will only exacerbate existing conditions and increase COVID-19 transmissions.

(J Med Internet Res 2021;23(2):e25454) doi: 10.2196/25454

\section{KEYWORDS}

COVID-19; SARS-CoV-2; SARS-CoV-2 surveillance; second wave; wave two; wave 2; global COVID-19 surveillance; Asia Pacific public health surveillance; Asia Pacific COVID-19; Asian Pacific SARS-CoV-2; Asia Pacific surveillance metrics; dynamic panel data; generalized method of the moments; Asian Pacific econometrics; East Asian Pacific COVID-19 surveillance system; Pacific Asian COVID-19 transmission speed; Asian Pacific COVID-19 transmission acceleration; COVID-19 transmission deceleration; COVID-19 transmission jerk; COVID-19 7-day lag; Arellano-Bond estimator; generalized method of moments; GMM; Australia; Brunei; Cambodia; China; Fiji; French Polynesia; Guam; Indonesia; Japan; Kiribati; Laos; Malaysia; Mongolia; Myanmar; New Caledonia; Philippines

\section{Introduction}

\section{Background}

COVID-19, caused by SARS-CoV-2, was first identified in Wuhan, Hubei Province, China, in December 2019 [1]. Since then, it has spread around the globe including to every country in the East Asia and Pacific region, severely straining governments, health care systems, economies, and quality of life globally (Figure 1). East Asia and the Pacific, as defined by the World Bank, consists of American Samoa, Australia, Brunei Darussalam, Cambodia, China, Fiji, French Polynesia, Guam, Hong Kong, Indonesia, Japan, Kiribati, People's Democratic Republic of Korea, Republic of Korea, Lao People's
Democratic Republic, Macao, Malaysia, Marshall Islands, Federated States of Micronesia, Mongolia, Myanmar, Nauru, New Caledonia, New Zealand, Northern Mariana Islands, Palau, Papua New Guinea, the Philippines, Samoa, Singapore, Solomon Islands, Thailand, Timor-Leste, Tonga, Tuvalu, Vanuatu, and Vietnam [2]. Not all of these countries collect or report COVID-19 caseloads and deaths, such as North Korea. As of October 28, 2020, the World Health Organization (WHO) reports a total of 43,540,739 cases and 1,160,650 deaths in these countries [3]. This global region encompasses countries of diverse income levels, political systems, cultures, populations, geography, climate, and health care systems, factors which have profoundly influenced not only the effects of the virus but also the response of each member country.

Figure 1. COVID-19 timeline in East Asia and the Pacific. WHO: World Health Organization. PDR: People's Democratic Republic.

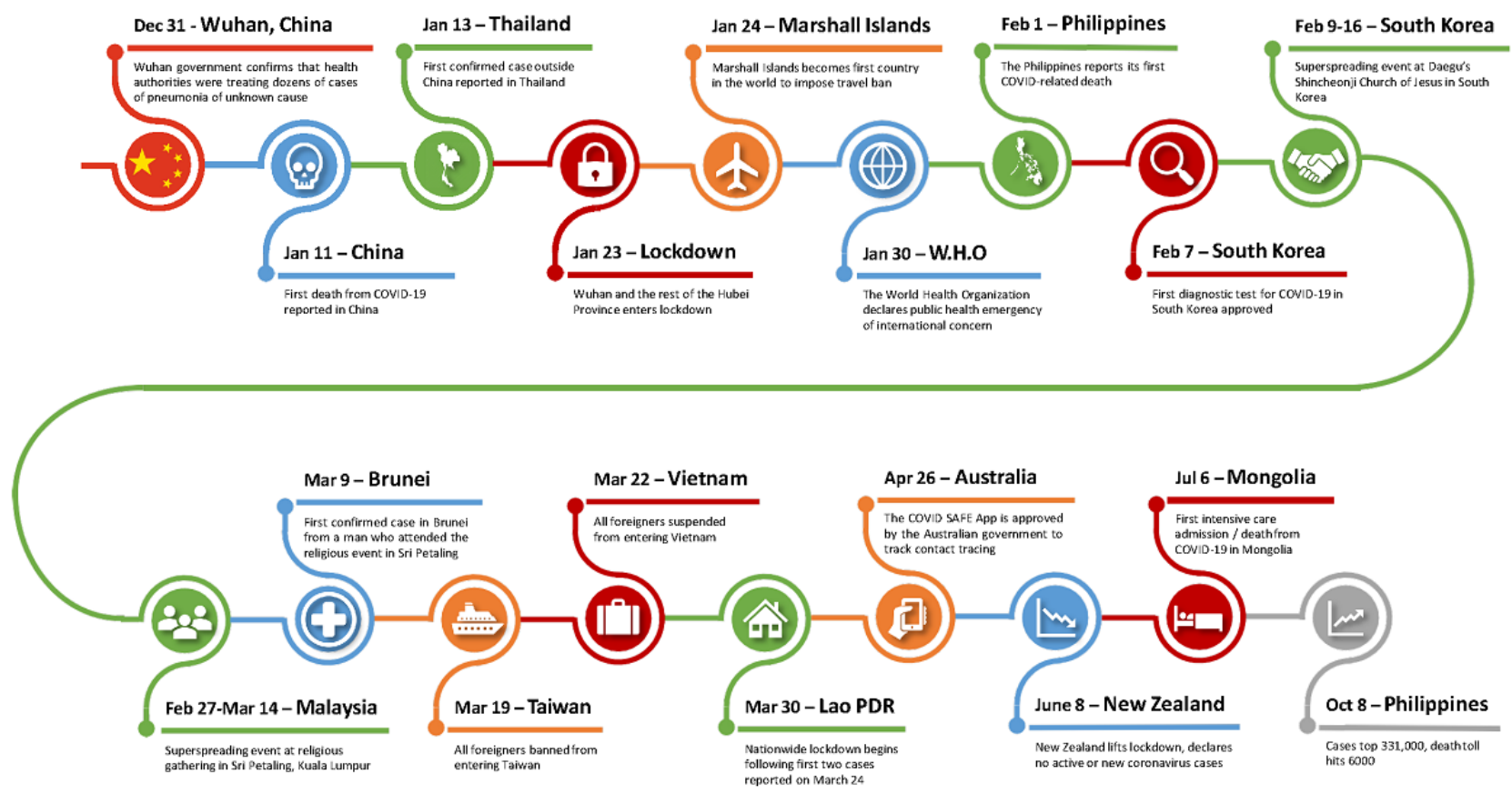

\section{Government Response and Public Health Policy}

The extreme quarantine implemented in Wuhan and the entire Hubei region of China mandated all residents to shelter in place without exception [4]. Wuhan imposed travel restrictions in and out of the city in addition to canceling gatherings, closing public places, and shutting down schools and universities [5]. China allocated significant resources for public health service and epidemic prevention and control [6].

The prompt response by East Asian countries was informed by the 2003 severe acute respiratory syndrome (SARS) and 2015 Middle East respiratory syndrome (MERS) outbreaks [7,8]. Singapore and Vietnam's strategy of comprehensive surveillance 
to detect and contain as many cases as possible has been highly successful in controlling or eliminating SARS-CoV-2 $[9,10]$. Taiwan's response to the 2003 SARS epidemic also informed COVID-19 response [11,12]. The Taiwan Centers for Disease Control aggressively traced confirmed cases while the government distributed masks and personal protection equipment $[13,14]$. Taiwan's interconnected public health, medical, and insurance infrastructure reduces barriers to doctor appointments and follow-up visits, allowing their health care system to capture more cases. Furthermore, their single-payer model allows for centralized health records of population-level longitudinal data, a valuable tool for analyzing the spread of the pandemic [11].

South Korea was the hardest hit country outside of the Middle East during the MERS outbreak in 2015, prompting the Korea Centers for Disease Control (KCDC) to prepare for the next infectious disease outbreak [15]. When COVID-19 breached Korea's borders, the KCDC actively performed contact tracing, quarantined exposed individuals, and diagnosed and isolated new cases with rapid and extensive testing [16-19].

New Zealand eradicated COVID-19 by introducing some of the strictest lockdown measures early on, allowing the government to pursue an elimination approach rather than the typical, mitigation-based model of pandemic planning. Schools and nonessential workplaces were closed, social gatherings banned, and severe travel restrictions applied [20-22]. Australia implemented similar though somewhat less stringent lockdown measures and border closures, resulting in substantially lower crude case fatality and hospitalization rates than many other high-income countries [23,24].

Some low- to middle-income countries such as Vietnam and Mongolia have also been able to implement successful responses to the pandemic despite limited resources or shared borders with China. As a result of Mongolia's travel restrictions, lockdown measures, and surveillance of active infections, they reported no confirmed cases until March 10, 2020, and no intensive care admissions or deaths until July 6, 2020 [25]. Vietnam responded immediately to its first cases by activating an emergency prevention system involving intense surveillance, quarantine, and contact tracing. Those who broke social distancing measures were severely punished. As of July 8, 2020, the nation had the highest test per confirmed case ratio in the world [26-31]. This approach differs vastly from the widespread testing strategy employed by South Korea, which, although seen by many as a best practice in fighting the pandemic, is more resource intensive [32].

In contrast, the Philippines has become Southeast Asia's coronavirus hotspot, overtaking Indonesia with a caseload exceeding 360,000 people with nearly 7000 deaths and no coherent strategy for defeating the virus [33]. Although their first case was reported in January 2020, a national lockdown was not enacted until March, and when citizens took to the streets to protest a lack of food and supplies 2 weeks later, President Rodrigo Duterte threatened that the police and military would shoot those who did not comply with stay-at-home orders [34-36]. Once the lockdown was lifted in June, cases quickly began to climb again. In addition, the Philippines was late to initiate COVID-19 measures including testing, isolation, and contact tracing [33]. Their result paralleled the United States with a similar outcome. The first wave is still raging through the islands while the second wave commences around the globe [37].

The Pacific Islands have been some of the least affected nations in the world due to their unique ability to shut down border traffic [38]. As of August 2, 2020, only 6 countries of the Pacific Islands (Papua New Guinea, Fiji, French Polynesia, Guam, New Caledonia, and Northern Mariana Islands) have recorded positive COVID-19 cases. Among the 12 countries without any confirmed cases, 10 are in this region (Kiribati, Marshall Islands, Micronesia, Nauru, Palau, Samoa, Solomon Islands, Tonga, Tuvalu, and Vanuatu). Furthermore, many nations recently strengthened their infectious disease prevention, surveillance, and response systems due to the re-emergence of measles in the area in 2019 [38-40].

\section{Health Systems, Vulnerable Populations, and Health Disparities}

The East Asia and Pacific region encompass a wide range of health care systems with varying capacities for pandemic preparedness. In New Zealand, approximately one-fifth of the government's spending goes to the health sector, and health services are either free or heavily subsidized [41]. In contrast, some of the world's smallest, least developed, and most isolated nations in need of health system strengthening are in the Pacific Islands region [42].

In the Philippines, $43 \%$ of the urban population lives in slums, and people living in densely populated urban slums are unlikely to have the space or economic means to practice social distancing $[43,44]$. The majority of Filipinos pay out of pocket for health care, a prohibitive cost that disproportionately affects the country's 7.5 million senior citizens, many of whom live in rural areas [45]. These barriers to access are exacerbated by the fact that hospitals in the Philippines are currently overwhelmed and reaching maximum capacity [45].

In Cambodia, more than 3 million people lack access to safe water, and 6 million lack access to improved sanitation. This disproportionately affects rural communities, where approximately $77 \%$ of Cambodians live, placing them at greater risk from the pandemic $[46,47]$.

Meanwhile, the pandemic has added an additional layer of complexity to Indonesia's longstanding problem of food insecurity and reliance on food imports. In 2018, 55\% of the Indonesian population experienced moderate or severe food insecurity. Unemployment and other loss of income associated with the pandemic have likely exacerbated this problem, with $70 \%$ of low-income households reporting a loss of income and about the same proportion reporting shortages of some foods or not eating as much as they should, placing 24 million children at risk of food insecurity [48].

Myanmar has attempted to combat the aggravating effects of food insecurity on its already underfunded health sector by providing emergency rations through strategies such as community-based food banks [49,50], although $10 \%-15 \%$ of 
the population report consuming reduced quantities of nutritious foods [51].

Individuals with underlying medical conditions are also known to be at greater risk of COVID-19. In Australia, Indigenous Australians constitute a uniquely vulnerable population due to the increased prevalence of diabetes and respiratory and cardiovascular conditions, as well as high reported smoking rates [52,53]. China is notorious for having the worst air pollution problem in the world, which may correlate with susceptibility to respiratory infections [54-56].

Despite early exposure, a high population density, an aging population, and little social distancing measures, Japan reports low rates of infection and death from COVID-19 [57,58]. This has led to some hypotheses that the Bacille Calmette-Guérin (BCG) vaccine against tuberculosis may protect against the virus, as countries that mandate the BCG vaccine have relatively low per capita death rates from COVID-19 [57,59].

\section{Economy}

Tourism is an important source of revenue for many economies in developing Asia and the Pacific [50,60,61]. For countries like Palau, where international tourism receipts are close to $50 \%$ of the GDP (gross domestic product) and over a third of international tourists are from China, the decline in tourism due to COVID-19 has been devastating [60].

China is a major trade destination for many developing Asian economies such as Mongolia, the Philippines, Singapore, Taipei, and Vietnam [60]. Long quarantine-like conditions have the potential to deeply harm export-based economies such as Mongolia, where coal exports were reduced due to border restrictions [25].

\section{Culture}

While Western cultures endorse individualism and a more independent self-concept, Eastern cultures emphasize collectivism and a concept of the self as interdependent with others, which may motivate individuals to remain committed to COVID-19 precautions even at the expense of personal freedoms [62]. Some of the actions that have enabled Asian countries to contain the spread of the virus have been challenging to Western notions of privacy and individual freedom; such measures have been almost universally accepted in Asian countries [26,32]. Therefore, interpersonal transmission of the virus may be less likely in East Asian countries [63].

Public health departments, as well as universities and media outlets, are tracking the novel coronavirus using raw data, including the number of new infections, testing, positivity, $\mathrm{R}_{0}$ (reproduction number), deaths, local hospital capacity, etc [39,64-93]. Public health surveillance informs policy on "flattening the curve" of COVID-19 [94-97]. Epidemiologists have utilized various modeling techniques to forecast the numbers of cases and deaths attributed to the virus [98-102]. Both the WHO and the Center for Systems Science and Engineering at Johns Hopkins University have developed tracking tools [98]. While helpful, these static metrics suffer from incomplete case ascertainment and data contamination $[94,96]$. Existing surveillance is a proxy for the true coronavirus caseload because public health surveillance systems tend to pick up the most severe cases [103,104], which is especially problematic when tracking SARS-CoV-2 because most carriers are asymptomatic, presymptomatic, or only have mild symptoms [105-108]. Public health surveillance that can control for these limitations are needed. Moreover, metrics that detect how transmission speed of the novel coronavirus, shifts in the pandemic, acceleration in speed, and persistence of COVID-19 based on prior infections are needed to supplement existing measures [83].

\section{Objective}

The objective of our research is to use a longitudinal trend analysis study design in concert with dynamic panel modeling and method of moments to correct for existing surveillance data limitations [94,96]. Specifically, we will measure significant weekly shifts in the increase, decrease, or plateaued transmission of SARS-CoV-2. Our study will measure the underlying causal effect from last week that persists through this week, with a 7-day persistence rate to explain a clustering/declustering effect. The 7-day persistence rate represents an underlying disease transmission wave, where a large number of transmissions that resulted in a large number of infections today then "echoes" forward into a large number of new transmissions and hence a large number of new cases 7 days later. If positive, it is consistent with, for example, a mega-event (eg, the large religious gathering at Daegu's Shincheonji Church of Jesus in South Korea) that causes an increase in the number of cases in adjoining days, among other explanations [16]. If zero or nonsignificant, it is indicative of a constant rate of new infections and/or a constant size of the infectious population. In summary, we will measure negative and positive shifts in the transmission of SARS-CoV-2 or acceleration/deceleration rates that are not limited by sampling bias.

\section{Methods}

We conducted a longitudinal trend analysis for our study design using data extracted from the internet. The COVID Tracking Project [109], Our World in Data [110], and The Foundation for Innovative New Diagnostics [111] compiles data from multiple sources on the web [112]; data for the most recent 4 weeks were accessed from the GitHub repository [113-115]. This resulted in a panel of 26 countries in East Asia and the Pacific with 30 days in each panel $(n=780)$. An empirical difference equation was specified in which the number of positive cases in each country for each day is a function of the prior number of cases, the level of testing, and weekly shift variables that measure whether the contagion was growing faster, at the same rate, or slower than the previous weeks. This resulted in a dynamic panel model that was estimated using the generalized method of moments (GMM) approach by implementing the Arellano-Bond estimator in $\mathrm{R}$ (The $\mathrm{R}$ Foundation) $[94,96,116]$. Additionally, we report on the novel dynamic surveillance metrics of speed, acceleration, and jerk [94,96]. 


\section{Results}

\section{Country Regression Results}

Regression results are presented for 26 East Asian and Pacific countries in Table 1. Weekly surveillance data in Tables 2-6 and Figure 2 [117] are based on these regressions.

The Wald statistic for the regression was significant $\left(\chi^{2}{ }_{5}=49,836,424 ; P<.001\right)$. The Sargan test was not significant, failing to reject the validity of overidentifying restrictions $\left(\chi_{294}^{2}=18 ; P=.99\right)$.

Table 1. Arellano-Bond dynamic panel data modeling of the number of daily infections reported by country in East Asia and the Pacific, October 5-18, 2020.

\begin{tabular}{lll}
\hline Variable & Statistic & $P$ value \\
\hline L1Pos $^{\mathrm{a}}$ & $r=-0.007$ & .89 \\
L7Pos $^{\mathrm{b}}$ & $r=0.887$ & $<.001$ \\
Cumulative tests & $r=0.000$ & .15 \\
Weekend & $r=-0.603$ & $<.001$ \\
Wald statistic for regression & $\chi^{2}{ }_{5}=49836424$ & $<.001$ \\
Sargan statistic for validity & $\chi^{2}{ }_{294}=18$ & .99 \\
\hline
\end{tabular}

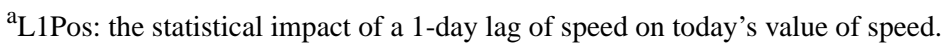

b 7 Pos: the statistical impact of the 7-day lag of speed on today's value of speed. New cases per day tend to have an echo effect 7 days later. Reported as the weekly average number of new cases per day that are attributable to the weekly average of the 7-day lag of the number of new cases per day.

Figure 2. COVID-19 weekly trends in East Asia and the Pacific [117].

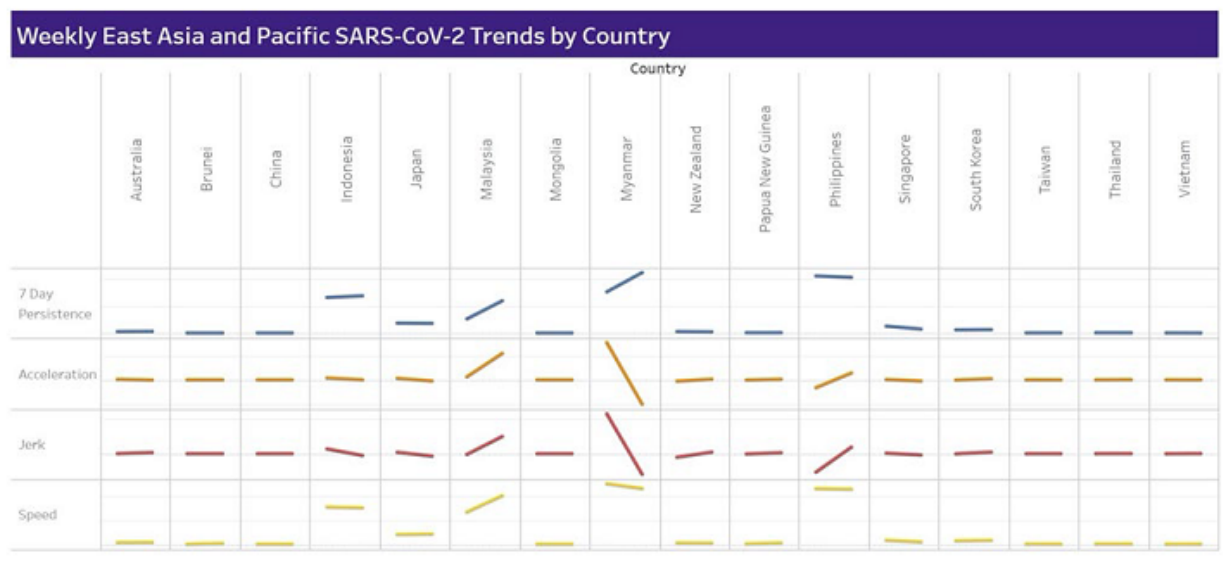

Table 2, for the week of October 5-11, and Table 3, for the week of October 12-18, present traditional surveillance metrics including new COVID-19 cases, cumulative COVID-19 cases, 7-day moving average of COVID-19 infections, infections per 100,000 population, deaths, cumulative deaths, and 7-day moving average of deaths rates per 100,000 population. Overall, in East Asia and the Pacific, by the second week, there were 9951 new daily cases of COVID-19, 1,076,042 cumulative cases of COVID-19, a 7-day moving average of 8005, an infection rate per 100,000 population of $0.4344,216$ daily deaths, and 28,053 cumulative deaths.
For the week of October 5-11, Indonesia led the East Asian and Pacific region with the highest number of new cases at 4294, followed by the Philippines at 2156 and Myanmar at 2158. The number of deaths follow the same pattern for Indonesia, the Philippines, and Myanmar at 88, 86, and 32 deaths, respectively.

For the week of October 12-18 (Table 3), Indonesia, the Philippines, and Myanmar continued to lead the region with 4301, 2588, and 1287 new COVID-19 infections and 84, 72, and 39 deaths, respectively. The cumulative number of deaths for the region reached 28,053 by the second week in October. 
Table 2. Static surveillance metrics for the week of October 5-11, 2020.

\begin{tabular}{|c|c|c|c|c|c|c|c|}
\hline Country & $\begin{array}{l}\text { New COVID-19 } \\
\text { cases, } \mathrm{n}\end{array}$ & $\begin{array}{l}\text { Cumulative COVID-19 } \\
\text { cases, } \mathrm{n}\end{array}$ & $\begin{array}{l}\text { 7-day moving aver- } \\
\text { age of new cases }\end{array}$ & $\begin{array}{l}\text { Rate of infec- } \\
\text { tion }\end{array}$ & $\begin{array}{l}\text { New } \\
\text { deaths, } \mathrm{n}\end{array}$ & $\begin{array}{l}\text { Cumulative } \\
\text { deaths, } \mathrm{n}\end{array}$ & $\begin{array}{l}\text { Death rate } \\
\text { per } 100 \mathrm{k}\end{array}$ \\
\hline Australia & 15 & 27,244 & 17.57 & 0.06 & 0 & 897 & 0 \\
\hline Brunei & 0 & 146 & 0 & 0 & 0 & 3 & 0 \\
\hline China & 21 & 90,778 & 24.86 & 0 & 0 & 4739 & 0 \\
\hline French Polynesia & 0 & 2692 & 104 & 0 & 0 & 10 & 0 \\
\hline Guam & 89 & 3078 & 54.14 & 53.20 & 2 & 60 & 1.20 \\
\hline Indonesia & 4294 & 328,952 & 4207 & 1.59 & 88 & 11,765 & 0.03 \\
\hline Japan & 679 & 88,912 & 510.43 & 0.54 & 3 & 1627 & 0 \\
\hline Malaysia & 374 & 15,096 & 429.71 & 1.17 & 3 & 155 & 0.01 \\
\hline Mongolia & 0 & 318 & 0 & 0 & 3 & 0 & 0.09 \\
\hline Myanmar & 2158 & 26,064 & 1365.86 & 3.99 & 32 & 598 & 0.06 \\
\hline New Zealand & 1 & 1515 & 2.43 & 0.02 & 0 & 25 & 0 \\
\hline Papua New Guinea & 0 & 549 & 1.29 & 0 & 0 & 7 & 0 \\
\hline Philippines & 2156 & 336,926 & 2514 & 1.99 & 86 & 6238 & 0.08 \\
\hline Singapore & 7 & $1,010,010$ & 9.43 & 0.12 & 0 & 27 & 0 \\
\hline South Korea & 58 & 57,866 & 73.57 & 0.11 & 2 & 432 & 0 \\
\hline Taiwan & 0 & 24,606 & 1.43 & 0 & 0 & 7 & 0 \\
\hline Thailand & 0 & 527 & 7.29 & 0 & 0 & 59 & 0 \\
\hline Vietnam & 2 & 3634 & 1.57 & 0 & 0 & 35 & 0 \\
\hline Region & 9854 & 1107 & 7999 & 0.43 & 219 & 26,684 & 0.01 \\
\hline
\end{tabular}


Table 3. Static surveillance metrics for the week of October 12-18, 2020.

\begin{tabular}{|c|c|c|c|c|c|c|c|}
\hline Country & $\begin{array}{l}\text { New COVID-19 } \\
\text { cases, n }\end{array}$ & $\begin{array}{l}\text { Cumulative COVID-19 } \\
\text { cases, } \mathrm{n}\end{array}$ & $\begin{array}{l}\text { 7-day moving aver- } \\
\text { age of new cases }\end{array}$ & $\begin{array}{l}\text { Rate of infec- } \\
\text { tion }\end{array}$ & $\begin{array}{l}\text { New } \\
\text { deaths, } n\end{array}$ & $\begin{array}{l}\text { Cumulative } \\
\text { deaths, } \mathrm{n}\end{array}$ & $\begin{array}{l}\text { Death rate } \\
\text { per } 100 \mathrm{k}\end{array}$ \\
\hline Australia & 12 & 27,383 & 19.86 & 0.05 & 0 & 904 & 0 \\
\hline Brunei & 0 & 147 & 0.14 & 0 & 0 & 3 & 0 \\
\hline China & 30 & 90,955 & 25.29 & 0 & 0 & 4739 & 0 \\
\hline French Polynesia & 62 & 3797 & 157.9 & 22.20 & 0 & 14 & 0 \\
\hline Guam & 0 & 3617 & 77.00 & 0 & 3 & 66 & 1.79 \\
\hline Indonesia & 4301 & 357,762 & 4115.71 & 1.59 & 84 & 12,431 & 0.03 \\
\hline Japan & 593 & 92,656 & 534.9 & 0.47 & 9 & 1670 & 0.01 \\
\hline Malaysia & 869 & 19,627 & 647.3 & 2.72 & 4 & 180 & 0.01 \\
\hline Mongolia & 0 & 324 & 0 & 0 & 4 & 0 & 0.12 \\
\hline Myanmar & 1387 & 34,875 & 1258.71 & 2.57 & 39 & 838 & 0.07 \\
\hline New Zealand & 3 & 1530 & 2.14 & 0.06 & 0 & 25 & 0 \\
\hline Papua New Guinea & 3 & 581 & 4.57 & 0.03 & 0 & 7 & 0 \\
\hline Philippines & 2588 & 354,338 & 2487.4 & 2.39 & 72 & 6603 & 0.07 \\
\hline Singapore & 3 & 57,904 & 5.43 & 0.05 & 0 & 28 & 0 \\
\hline South Korea & 91 & 25,199 & 84.71 & 0.18 & 1 & 444 & 0 \\
\hline Taiwan & 0 & 535 & 1.14 & 0 & 0 & 7 & 0 \\
\hline Thailand & 7 & 3686 & 7.43 & 0.01 & 0 & 59 & 0 \\
\hline Vietnam & 2 & 1126 & 2.71 & 0 & 0 & 35 & 0 \\
\hline Region & 9951 & $1,076,042$ & 8005 & 0.44 & 216 & 28,053 & 0.01 \\
\hline
\end{tabular}

Tables 4 and 5 provide the novel surveillance metrics for the weeks of October 5-11 and October 12-18, respectively. During the week of October 5-11 (Table 4), French Polynesia had the highest speed or velocity of new cases at 37 per 100,000 population, followed by Guam at 32.6 cases per 100,000 population. The highest rates of acceleration per 100,000 population was 0.312 for Myanmar, 0.025 for Malaysia, and 0.015 for Indonesia. The highest jerk rates were $0.228,0.027$, and 0.008 for Myanmar, Indonesia, and Japan, respectively. French Polynesia and Guam ranked 1 and 2 for 7-day persistence at 28.68 and 25.14, respectively, meaning these cases were statically attributed to those persons infected 7 days earlier. 
Table 4. Novel surveillance metrics for the week of October 5-11, 2020.

\begin{tabular}{|c|c|c|c|c|}
\hline Country & Speed $^{\mathrm{a}}$ & Acceleration $^{\mathrm{b}}$ & Jerk $^{\mathrm{c}}$ & 7-day persistence effect on speed ${ }^{d}$ \\
\hline Australia & 0.07 & 0 & 0 & 0.05 \\
\hline Brunei & 0 & 0 & 0 & 0 \\
\hline China & 0 & 0 & 0 & 0 \\
\hline French Polynesia & 37.24 & 0 & -11.66 & 28.69 \\
\hline Guam & 32.36 & -5.12 & -9.82 & 26.14 \\
\hline Indonesia & 1.55 & 0.02 & 0.03 & 1.32 \\
\hline Japan & 0.40 & 0.01 & 0.01 & 0.37 \\
\hline Malaysia & 1.34 & 0.03 & 0 & 0.52 \\
\hline Mongolia & 0 & 0 & 0 & 0 \\
\hline Myanmar & 2.53 & 0.31 & 0.23 & 1.53 \\
\hline New Zealand & 0.05 & -0.01 & -0.02 & 0.05 \\
\hline Papua New Guinea & 0.01 & 0 & 0 & 0.01 \\
\hline Philippines & 2.33 & -0.07 & -0.11 & 2.12 \\
\hline Singapore & 0.17 & 0 & 0 & 0.26 \\
\hline South Korea & 0.14 & 0 & 0 & 0.12 \\
\hline Taiwan & 0.01 & 0 & 0 & 0 \\
\hline Thailand & 0.01 & 0 & 0 & 0.01 \\
\hline Vietnam & 0 & 0 & 0 & 0 \\
\hline Region & 0.41 & 0.01 & 0 & 0.33 \\
\hline
\end{tabular}

${ }^{\mathrm{a}}$ Daily positives per 100k (weekly average of new daily cases per 100k).

${ }^{\mathrm{b}}$ Day-to-day change in the number of positives per day, weekly average, per 100k.

${ }^{\mathrm{c}}$ Week-over-week change in acceleration, per 100k.

${ }^{\mathrm{d}}$ New cases per day per 100k attributed to new cases 7 days ago.

Table 5 presents the novel surveillance metrics for the second week of our study period. Between October 12 and 18, French Polynesia ranked first in speed of new infections at 56.5 per 100,000 , followed by Guam at 46 per 100,000. French Polynesia and Guam are several standard deviations higher than the rest of the East Asian and Pacific region. French Polynesia had the highest acceleration rate at 3.17 per 100,000 population, and

Polynesia had the highest positive jerk at 15.4 per 100,000 population. French Polynesia and Guam had the largest 7-day persistence during the October 12-18 period (Table 6). In summary, French Polynesia, Malaysia, the Philippines, South Korea, and New Zealand have positive speeds, acceleration, jerks, and 7-day persistence, indicating an upwards shift in the pandemic. 
Table 5. Novel surveillance metrics for the week of October 12-18, 2020.

\begin{tabular}{|c|c|c|c|c|}
\hline Country & Speed $^{\mathrm{a}}$ & Acceleration $^{\mathrm{b}}$ & Jerk $^{\mathrm{c}}$ & 7-day persistence effect on speed ${ }^{d}$ \\
\hline Australia & 0.08 & 0 & 0.01 & 0.06 \\
\hline Brunei & 0.03 & 0 & 0 & 0 \\
\hline China & 0 & 0 & 0 & 0 \\
\hline French Polynesia & 56.52 & 3.17 & 15.45 & 33.04 \\
\hline Guam & 46.03 & -7.60 & -19.13 & 28.72 \\
\hline Indonesia & 1.52 & 0 & -0.01 & 1.38 \\
\hline Japan & 0.42 & -0.01 & -0.01 & 0.36 \\
\hline Malaysia & 2.03 & 0.22 & 0.10 & 1.19 \\
\hline Mongolia & 0 & 0 & 0 & 0 \\
\hline Myanmar & 2.33 & -0.20 & -0.12 & 2.24 \\
\hline New Zealand & 0.04 & 0.01 & 0.01 & 0.04 \\
\hline Papua New Guinea & 0.05 & 0 & 0 & 0.01 \\
\hline Philippines & 2.30 & 0.06 & 0.04 & 2.06 \\
\hline Singapore & 0.10 & -0.01 & -0.01 & 0.15 \\
\hline South Korea & 0.16 & 0.01 & 0.01 & 0.13 \\
\hline Taiwan & 0 & 0 & 0 & 0.01 \\
\hline Thailand & 0.01 & 0 & 0 & 0.01 \\
\hline Vietnam & 0 & 0 & 0 & 0 \\
\hline Region & 0.41 & 0 & 0 & 0.36 \\
\hline
\end{tabular}

${ }^{\mathrm{a}}$ Daily positives per 100k (weekly average of new daily cases per 100k).

${ }^{\mathrm{b}}$ Day-to-day change in the number of positives per day, weekly average, per 100k.

${ }^{\mathrm{c}}$ Week-over-week change in acceleration, per 100k.

${ }^{\mathrm{d}}$ New cases per day per 100k attributed to new cases 7 days ago.

Table 6. Seven-day persistence difference.

\begin{tabular}{lll}
\hline Country & $\begin{array}{l}\text { 7-day persistence } \\
\text { October 11, 2020 }\end{array}$ & October 18, 2020 \\
\hline French Polynesia & 28.69 & 33.04 \\
Guam & 26.14 & 28.72 \\
Philippines & 2.12 & 2.06 \\
Myanmar & 1.53 & 2.24 \\
Indonesia & 1.32 & 1.38 \\
\hline
\end{tabular}

The most populous countries in East Asia and Pacific include China, Indonesia, Japan, Philippines, and Vietnam (Table 7).

Countries with larger populations are at risk for having more COVID-19 infections by virtue of size, but this was not necessarily the case when comparing population size to the speed, acceleration, jerks, and 7-day persistence in Tables 4 and 5.

For comprehensive surveillance of static or traditional surveillance metrics with novel surveillance metrics for East Asia and Pacific, see Multimedia Appendices 1-3. 
Table 7. Most populous East Asian countries.

\begin{tabular}{ll}
\hline Country $^{\text {a }}$ & Population as of 2020, N \\
\hline China & $1,439,323,776$ \\
Indonesia & $273,523,615$ \\
Japan & $126,476,461$ \\
Philippines & $109,581,078$ \\
Vietnam & $97,338,579$ \\
\hline
\end{tabular}

${ }^{\mathrm{a}}$ Does not include countries that do not track or report COVID-19 cases (eg, North Korea).

\section{Discussion}

Countries in the East Asia and Pacific region have had differential success in combating the COVID-19 pandemic, with some countries among the most successful in the world at containing the pandemic and others in serious jeopardy. China, Taiwan, South Korea, and Japan had early outbreaks that were successfully contained through stringent protective measures. Some of the smaller islands in the Pacific encountered the disease much later than other countries, but after initial exposure, French Polynesia and Malaysia had outbreaks that swiftly affected their nations.

While South Korea, New Zealand, and Australia are demonstrating some increases in speed, acceleration, jerk, and 7-day persistence, these nations had successfully implemented COVID-19 control policies that literally eliminated COVID-19. However, as wave two of the COVID-19 pandemic has recently began the cycle of transmissions, these countries had either low caseloads or zero caseloads; hence, any new cases are going to result in increased rates of transmission. The new cases in countries that previously eradicated COVID-19 indicate a need to reinstate public health guidelines to keep the second wave of COVID-19 transmission from gaining a larger foothold. Moreover, other countries in East Asia and the Pacific who are presently dealing with the first wave will have novel infections from wave two as well, such as Indonesia and the Philippines who have the highest cumulative infections and cumulative deaths from COVID-19. While the Philippines was decelerating during the week of October 5-11, it reversed course and now has a positive acceleration.

The region's biggest successes are Singapore, New Zealand, Vietnam, South Korea, and China. In theory, it is likely easier to control for outbreaks in island nations such as Singapore and New Zealand; however, not all islands experienced their level of prevention and mitigation. Moreover, relative to population size (Table 7), South Korea, Vietnam, and China experienced an initial COVID-19 outbreak and took preventative measures to control further spread successfully.

\section{Acknowledgments}

This publication was made possible through support provided by Feed the Future through the US Agency for International Development, under the terms of contract \#7200LA1800003. The opinions expressed herein are those of the author(s) and do not necessarily reflect the views of the US Agency for International Development.

\section{Conflicts of Interest}

None declared.

\section{Multimedia Appendix 1}

Weekly East Asia and Pacific 7-day persistence map.

[PNG File, 331 KB-Multimedia Appendix 1]

\section{Multimedia Appendix 2}

Weekly East Asia and Pacific acceleration jerk map.

[PNG File, 392 KB-Multimedia Appendix 2]

\section{Multimedia Appendix 3}

Weekly East Asia and Pacific statistics.

[PNG File, 265 KB-Multimedia Appendix 3]

\section{References}


1. COVID-19 Overview and Infection Prevention and Control Priorities in Non-US Healthcare Settings. Centers for Disease Control and Prevention. 2020. URL: https://www.cdc.gov/coronavirus/2019-ncov/hcp/non-us-settings/overview/index.html [accessed 2020-08-06]

2. East Asia and Pacific. The World Bank. URL: https://data.worldbank.org/region/east-asia-and-pacific [accessed 2020-08-02]

3. WHO Coronavirus Disease (COVID-19) Dashboard. World Health Organization. 2020. URL: https://covid19.who.int/table [accessed 2020-10-28]

4. Cyranoski D. What China's coronavirus response can teach the rest of the world. Nature 2020 Mar 17;579(7800):479-480. [doi: 10.1038/d41586-020-00741-x] [Medline: 32203360]

5. Lau H, Khosrawipour V, Kocbach P, Mikolajczyk A, Schubert J, Bania J, et al. The positive impact of lockdown in Wuhan on containing the COVID-19 outbreak in China. J Travel Med 2020 May 18;27(3):37-51 [FREE Full text] [doi: 10.1093/jtm/taaa037] [Medline: 32181488$]$

6. Zhang S, Wang Z, Chang R, Wang H, Xu C, Yu X, et al. COVID-19 containment: China provides important lessons for global response. Front Med 2020 Apr 25;14(2):215-219 [FREE Full text] [doi: 10.1007/s11684-020-0766-9] [Medline: 32212059]

7. Coronaviridae Study Group of the International Committee on Taxonomy of Viruses. The species severe acute respiratory syndrome-related coronavirus: classifying 2019-nCoV and naming it SARS-CoV-2. Nat Microbiol 2020 Apr 2;5(4):536-544 [FREE Full text] [doi: 10.1038/s41564-020-0695-z] [Medline: $\underline{32123347]}$

8. Frieden TR, Lee CT. Identifying and Interrupting Superspreading Events-Implications for Control of Severe Acute Respiratory Syndrome Coronavirus 2. Emerg Infect Dis 2020 Jun;26(6):1059-1066 [FREE Full text] [doi: 10.3201/eid2606.200495] [Medline: 32187007$]$

9. Ng Y, Li Z, Chua YX, Chaw WL, Zhao Z, Er B, et al. Evaluation of the Effectiveness of Surveillance and Containment Measures for the First 100 Patients with COVID-19 in Singapore - January 2-February 29, 2020. MMWR Morb Mortal Wkly Rep 2020 Mar 20;69(11):307-311 [FREE Full text] [doi: 10.15585/mmwr.mm6911e1] [Medline: 32191691]

10. Lee VJ, Chiew CJ, Khong WX. Interrupting transmission of COVID-19: lessons from containment efforts in Singapore. J Travel Med 2020 May 18;27(3):39 [FREE Full text] [doi: 10.1093/jtm/taaa039] [Medline: 32167146]

11. Lin C, Braund WE, Auerbach J, Chou J, Teng J, Tu P, et al. Policy Decisions and Use of Information Technology to Fight COVID-19, Taiwan. Emerg Infect Dis 2020 Jul;26(7):1506-1512 [FREE Full text] [doi: 10.3201/eid2607.200574] [Medline: 32228808]

12. Wang CJ, Ng CY, Brook RH. Response to COVID-19 in Taiwan: Big Data Analytics, New Technology, and Proactive Testing. JAMA 2020 Apr 14;323(14):1341-1342. [doi: 10.1001/jama.2020.3151] [Medline: 32125371]

13. Steinbrook R. Contact Tracing, Testing, and Control of COVID-19-Learning From Taiwan. JAMA Intern Med 2020 Sep 01;180(9):1163-1164. [doi: 10.1001/jamainternmed.2020.2072] [Medline: 32356871]

14. Chang CM, Tan TW, Ho TC, Chen CC, Su TH, Lin CY. COVID-19: Taiwan's epidemiological characteristics and public and hospital responses. PeerJ 2020;8:e9360 [FREE Full text] [doi: 10.7717/peerj.9360] [Medline: 32551205]

15. Her M. Repurposing and reshaping of hospitals during the COVID-19 outbreak in South Korea. One Health 2020 Dec;10:100137 [FREE Full text] [doi: 10.1016/j.onehlt.2020.100137] [Medline: $\underline{\text { 32373705] }}$

16. Choi JY. COVID-19 in South Korea. Postgrad Med J 2020 Jul 04;96(1137):399-402. [doi: 10.1136/postgradmedj-2020-137738] [Medline: 32366457]

17. Kim KH, Choi EH, Kim SK. Editorial. COVID-19 outbreak and its countermeasures in the Republic of Korea. J Neurosurg 2020 Apr 17:1-2 [FREE Full text] [doi: 10.3171/2020.4.JNS201062] [Medline: 32302997]

18. Her M. How is COVID-19 affecting South Korea? What is our current strategy? Disaster Med Public Health Prep 2020 Apr 03:1-7. [doi: 10.1017/dmp.2020.69] [Medline: 32241325]

19. Choi S, Han C, Lee J, Kim S, Kim IB. Innovative screening tests for COVID-19 in South Korea. Clin Exp Emerg Med 2020 Jun 16;7(2):73-77 [FREE Full text] [doi: 10.15441/ceem.20.032] [Medline: 32295319]

20. Cousins S. New Zealand eliminates COVID-19. The Lancet 2020 May;395(10235):1474. [doi: 10.1016/s0140-6736(20)31097-7]

21. Klein A. New Zealand's success. New Scientist 2020 May;246(3282):9. [doi: 10.1016/s0262-4079(20)30908-8]

22. Varghese $\mathrm{C}, \mathrm{Xu}$ W. Quantifying what could have been - The impact of the Australian and New Zealand governments' response to COVID-19. Infect Dis Health 2020 Nov;25(4):242-244 [FREE Full text] [doi: 10.1016/j.idh.2020.05.003] [Medline: 32507662$]$

23. Andrikopoulos S, Johnson G. The Australian response to the COVID-19 pandemic and diabetes - Lessons learned. Diabetes Res Clin Pract 2020 Jul;165:108246 [FREE Full text] [doi: 10.1016/j.diabres.2020.108246] [Medline: 32502693]

24. Antony J, James WT, Neriamparambil AJ, Barot DD, Withers T. An Australian Response to the COVID-19 Pandemic and Its Implications on the Practice of Neurosurgery. World Neurosurg 2020 Jul;139:e864-e871 [FREE Full text] [doi: 10.1016/j.wneu.2020.05.136] [Medline: 32450310]

25. Erkhembayar R, Dickinson E, Badarch D, Narula I, Warburton D, Thomas GN, et al. Early policy actions and emergency response to the COVID-19 pandemic in Mongolia: experiences and challenges. The Lancet Global Health 2020 Sep;8(9):e1234-e1241. [doi: 10.1016/s2214-109x(20)30295-3] 
26. Dao TL, Nguyen TD, Hoang VT. Controlling the COVID-19 pandemic: Useful lessons from Vietnam. Travel Med Infect Dis 2020 Sep;37:101822 [FREE Full text] [doi: 10.1016/j.tmaid.2020.101822] [Medline: 32653477]

27. Duong DM, Le VT, Ha BTT. Controlling the COVID-19 Pandemic in Vietnam: Lessons From a Limited Resource Country. Asia Pac J Public Health 2020 May 19;32(4):161-162. [doi: 10.1177/1010539520927290] [Medline: 32429676]

28. Ha BTT, Ngoc Quang L, Mirzoev T, Tai NT, Thai PQ, Dinh PC. Combating the COVID-19 Epidemic: Experiences from Vietnam. Int J Environ Res Public Health 2020 Apr 30;17(9):3125 [FREE Full text] [doi: 10.3390/ijerph17093125] [Medline: 32365851]

29. Hoang VM, Hoang HH, Khuong QL, La NQ, Tran TTH. Describing the pattern of the COVID-19 epidemic in Vietnam. Glob Health Action 2020 Dec 31;13(1):1776526 [FREE Full text] [doi: 10.1080/16549716.2020.1776526] [Medline: 32588779]

30. Nguyen TH, Vu DC. Summary of the COVID-19 outbreak in Vietnam - Lessons and suggestions. Travel Med Infect Dis 2020 Sep;37:101651 [FREE Full text] [doi: 10.1016/j.tmaid.2020.101651] [Medline: 32247928]

31. Van Nguyen H, Van Hoang M, Dao ATM, Nguyen HL, Van Nguyen T, Nguyen PT, et al. An adaptive model of health system organization and responses helped Vietnam to successfully halt the Covid-19 pandemic: What lessons can be learned from a resource-constrained country. Int J Health Plann Manage 2020 Sep 18;35(5):988-992 [FREE Full text] [doi: 10.1002/hpm.3004] [Medline: 32557815]

32. Trevisan M, Le LC, Le AV. The COVID-19 Pandemic: A View From Vietnam. Am J Public Health 2020 Aug;110(8):1152-1153. [doi: 10.2105/ajph.2020.305751]

33. Sullivan M. The Philippines Becomes Coronavirus Hot Spot In Southeast Asia. NPR. 2020 Aug 10. URL: https://www. npr.org/2020/08/10/900279722/the-philippines-becomes-coronavirus-hot-spot-in-southeast-asia [accessed 2020-08-13]

34. Lo B, Ott H. The Philippines has the worst coronavirus outbreak in Southeast Asia, and critics warn the government could use it to crack down on dissent. CBS News. 2020 Aug 07. URL: https://www.cbsnews.com/news/ covid-19-philippines-worst-coronavirus-outbreak-in-southeast-asia-crackdown-on-dissent/ [accessed 2020-08-13]

35. Westcott B, Lagamayo A. Critics are accusing the Philippines government of using the coronavirus lockdown to crack down on dissent. CNN. 2020 Aug 03. URL: https://www.cnn.com/2020/08/03/asia/philippines-coronavirus-duterte-intl-hnk/ index.html [accessed 2020-08-13]

36. Capatides C. "Shoot them dead": Philippine President Rodrigo Duterte orders police and military to kill citizens who defy coronavirus lockdown. CBS News. 2020 Apr 02. URL: https://www.cbsnews.com/news/ rodrigo-duterte-philippines-president-coronavirus-lockdown-shoot-people-dead/ [accessed 2020-08-13]

37. Moghnieh R, Abdallah D, Bizri AR. COVID-19: Second Wave or Multiple Peaks, Natural Herd Immunity or Vaccine We Should be Prepared. Disaster Med Public Health Prep 2020 Sep 10:1-8 [FREE Full text] [doi: 10.1017/dmp.2020.349] [Medline: $\underline{\text { 32907693] }}$

38. Diarra I, Muna L, Diarra U. How the Islands of the South Pacific have remained relatively unscathed in the midst of the COVID-19 pandemic. J Microbiol Immunol Infect 2020 Jul 10:6-15 [FREE Full text] [doi: 10.1016/j.jmii.2020.06.015] [Medline: 32665107]

39. COVID-19 Dashboard by the Center for Systems Science and Engineering (CSSE) at Johns Hopkins University. Center for Systems Science and Engineering at Johns Hopkins University. 2020. URL: https://coronavirus.jhu.edu/map.html [accessed 2020-09-11]

40. Kerbaj C, Cazorla C, De Greslan T, Serie M, Gourinat AC, Marot B. COVID-19: The New Caledonia Experience. Clin Infect Dis 2020 Nov 19;71(16):2279-2281 [FREE Full text] [doi: 10.1093/cid/ciaa600] [Medline: 32415955]

41. Bandyopadhyay G, Meltzer A. Let us unite against COVID-19 - a New Zealand perspective. Ir J Psychol Med 2020 May 14:1-4 [FREE Full text] [doi: 10.1017/ipm.2020.44] [Medline: $\underline{\text { 32404225] }}$

42. Craig AT, Heywood AE, Hall J. Risk of COVID-19 importation to the Pacific islands through global air travel. Epidemiol Infect 2020 Mar 23;148:e71 [FREE Full text] [doi: 10.1017/S0950268820000710] [Medline: 32202489]

43. Lau LL, Hung N, Go DJ, Ferma J, Choi M, Dodd W, et al. Knowledge, attitudes and practices of COVID-19 among income-poor households in the Philippines: A cross-sectional study. J Glob Health 2020 Jun;10(1):011007 [FREE Full text] [doi: 10.7189/jogh.10.011007] [Medline: $\underline{32566169}$ ]

44. World Development Indicators. World Bank Group. 2020. URL: https://databank.worldbank.org/source/ world-development-indicators [accessed 2020-08-13]

45. Buenaventura RD, Ho JB, Lapid MI. COVID-19 and mental health of older adults in the Philippines: a perspective from a developing country. Int Psychogeriatr 2020 Oct;32(10):1129-1133 [FREE Full text] [doi: 10.1017/S1041610220000757] [Medline: 32349826]

46. Cambodia's water and sanitation crisis. Water.org. 2020. URL: https://water.org/our-impact/where-we-work/cambodia/ [accessed 2020-08-02]

47. Water, Sanitation and Hygiene. UNICEF Cambodia. 2020. URL: https://www.unicef.org/cambodia/ water-sanitation-and-hygiene [accessed 2020-08-02]

48. COVID-19 Economic and Food Security Implications for Indonesia. WFP. 2020. URL: https://www.wfp.org/publications/ covid-19-economic-and-food-security-implications-indonesia-3rd-edition-august-2020 [accessed 2020-11-01] 
49. COVID-19 Policy Response (CPR) Portal. International Food Policy Research Institute. 2020. URL: https://www.ifpri.org/ project/covid-19-policy-response-cpr-portal [accessed 2020-08-14]

50. Grundy-Warr C, Lin S. COVID-19 geopolitics: silence and erasure in Cambodia and Myanmar in times of pandemic. Eurasian Geography and Economics 2020 Jun 16;61(4-5):493-510. [doi: 10.1080/15387216.2020.1780928]

51. Impacts of COVID-19 on Myanmar's agri-food system: Evidence base and policy implications. International Food Policy Research Institute. 2020. URL: https://www.ifpri.org/publication/ impacts-covid-19-myanmars-agri-food-system-evidence-base-and-policy-implications [accessed 2020-08-03]

52. Desborough J, Hall Dykgraaf S, de Toca L, Davis S, Roberts L, Kelaher C, et al. Australia's national COVID-19 primary care response. Med J Aust 2020 Aug 04;213(3):104-106.e1 [FREE Full text] [doi: 10.5694/mja2.50693] [Medline: 32623740]

53. Furlong Y, Finnie T. Culture counts: the diverse effects of culture and society on mental health amidst COVID-19 outbreak in Australia. Ir J Psychol Med 2020 Sep 14;37(3):237-242 [FREE Full text] [doi: 10.1017/ipm.2020.37] [Medline: 32406358]

54. Xu H, Yan C, Fu Q, Xiao K, Yu Y, Han D, et al. Possible environmental effects on the spread of COVID-19 in China. Sci Total Environ 2020 Aug 20;731:139211 [FREE Full text] [doi: 10.1016/j.scitotenv.2020.139211] [Medline: 32402910 ]

55. Kan H, Chen B, Hong C. Health impact of outdoor air pollution in China: current knowledge and future research needs. Environ Health Perspect 2009 May;117(5):A187 [FREE Full text] [doi: 10.1289/ehp.12737] [Medline: 19478975]

56. Zhu Y, Xie J, Huang F, Cao L. Association between short-term exposure to air pollution and COVID-19 infection: Evidence from China. Science of The Total Environment 2020 Jul 20;727:138704. [doi: 10.1016/j.scitotenv.2020.138704]

57. Iwasaki A, Grubaugh ND. Why does Japan have so few cases of COVID-19? EMBO Mol Med 2020 May 08;12(5):e12481 [FREE Full text] [doi: 10.15252/emmm.202012481] [Medline: 32275804]

58. Hamidi S, Sabouri S, Ewing R. Does Density Aggravate the COVID-19 Pandemic? Journal of the American Planning Association 2020 Jun 18;86(4):495-509. [doi: 10.1080/01944363.2020.1777891]

59. O'Neill LAJ, Netea MG. BCG-induced trained immunity: can it offer protection against COVID-19? Nat Rev Immunol 2020 Jun 11;20(6):335-337 [FREE Full text] [doi: 10.1038/s41577-020-0337-y] [Medline: $\underline{32393823}$ ]

60. Abiad A, Arao RM, Dagil S, Ferrarini B, Noy I, Osewe P, et al. The Economic Impact of the COVID-19 Outbreak on Developing Asia. Asian Development Bank 2020 Mar:1-14 [FREE Full text] [doi: 10.22617/BRF200096]

61. Yamano T, Pradhananga M, Schipani S, Samson JNG, Quiao L, Leuangkhamsing S, et al. The Impact of COVID-19 on Tourism Enterprises in the Lao People's Democratic Republic: An Initial Assessment. Asian Development Bank 2020 Jun:1-8 [FREE Full text] [doi: 10.22617/brf200187-2]

62. Burgess A, Horii M. Risk, ritual and health responsibilisation: Japan's 'safety blanket' of surgical face mask-wearing. Sociol Health Illn 2012 Nov;34(8):1184-1198 [FREE Full text] [doi: 10.1111/j.1467-9566.2012.01466.x] [Medline: 22443378]

63. Bavel JJV, Baicker K, Boggio PS, Capraro V, Cichocka A, Cikara M, et al. Using social and behavioural science to support COVID-19 pandemic response. Nat Hum Behav 2020 May 30;4(5):460-471. [doi: 10.1038/s41562-020-0884-z] [Medline: $\underline{32355299]}$

64. Coronavirus World Map: Tracking the Global Outbreak. The New York Times. 2020. URL: https://www.nytimes.com/ interactive/2020/world/coronavirus-maps.html [accessed 2020-08-12]

65. Tracking coronavirus' global spread. CNN. 2020. URL: https://www.cnn.com/interactive/2020/health/ coronavirus-maps-and-cases/ [accessed 2020-08-12]

66. Coronavirus Disease-19, Republic of Korea. Ministry of Health and Welfare of Korea. 2020. URL: http://ncov.mohw.go.kr/ en/ [accessed 2020-08-12]

67. COVID-19 (SARS-CoV-2-infection). Centers for Disease Control and Prevention. 2020. URL: https://www.cdc.gov.tw/ En [accessed 2020-08-12]

68. COVID-19 - current cases. Ministry of Health of New Zealand. 2020. URL: https://www.health.govt.nz/our-work/ diseases-and-conditions/covid-19-novel-coronavirus/covid-19-current-situation/covid-19-current-cases [accessed 2020-08-12]

69. About Coronavirus Disease 2019 (COVID-19). Ministry of Health, Labour, and Welfare - Japan. 2020. URL: https://www. mhlw.go.jp/stf/seisakunitsuite/bunya/newpage 00032.html [accessed 2020-08-12]

70. Coronavirus (COVID-19) health alert. Australian Government Department of Health. 2020. URL: https://www.health.gov.au/ news/health-alerts/novel-coronavirus-2019-ncov-health-alert [accessed 2020-08-14]

71. COVID-19 Dashboard. Brunei Darussalam Ministry of Health. 2020. URL: www.healthinfo.gov.bn [accessed 2020-08-14]

72. COVID-19 Information. US Embassy in Cambodia. 2020. URL: https://kh.usembassy.gov/covid-19-information/ [accessed 2020-08-14]

73. Aug 14: Daily briefing on novel coronavirus cases in China. National Health Commission of the People's Republic of China. 2020. URL: http://en.nhc.gov.cn/2020-08/14/c_81388.htm [accessed 2020-08-14]

74. COVID-19 Updates. Fiji Ministry of Health and Medical Services. 2020. URL: http://www.health.gov.fj/covid-19-updates/ [accessed 2020-08-14]

75. Guam COVID-19 Dashboard. Department of Public Health and Social Services. 2020. URL: http://dphss.guam.gov/covid-19/ [accessed 2020-08-14]

76. Coronavirus Disease (COVID-19) in Hong Kong. The Government of the Hong Kong Special Administrative Region. 2020. URL: https://www.coronavirus.gov.hk/eng/index.html [accessed 2020-08-14] 
77. COVID-19. Ministry of Health Republic of Indonesia. 2020. URL: https://www.kemkes.go.id/index.php?lg=LN02 [accessed 2020-08-14]

78. Ad hoc committee COVID-19. Ministry of Health - Laos. 2020. URL: https://www.covid19.gov.la/index.php [accessed 2020-08-14]

79. Home |COVID-19 Malaysia. Ministry of Health of Malaysia. 2020. URL: http://covid-19.moh.gov.my/ [accessed 2020-08-14]

80. RMI Covid-19 Update. Marshall Islands National Disaster Management Office. 2020. URL: https://ndmo.gov.mh/ [accessed 2020-08-14]

81. COVID-19 Information. US Embassy in the Federated States of Micronesia. 2020. URL: https://fm.usembassy.gov/ covid-19-information/ [accessed 2020-08-14]

82. COVID-19. Ministry of Health of Mongolia. 2020. URL: https://covid19.mohs.mn/ [accessed 2020-08-14]

83. COVID-19 (Coronavirus Disease 2019) Acute Respiratory Disease. The Republic of the Union of Myanmar- Ministry of Health and Sports. 2020. URL: https://www.mohs.gov.mm/Main/content/publication/2019-ncov [accessed 2020-08-14]

84. COVID-19. Department of Health and Medicinal Service. 2020. URL: http://www.naurugov.nr/government/departments/ department-of-health-and-medicinal-service/covid-19.aspx [accessed 2020-08-14]

85. CNMI COVID-19 Dashboard. Commonwealth Healthcare Corporation - Commonwealth of the Northern Mariana Islands. 2020. URL: https://cnmichcc.maps.arcgis.com/apps/opsdashboard/index.html\#/4061b674fc964efe84f7774b7979d2b5 [accessed 2020-08-14]

86. COVID-19. Ministry of Health Republic of Palau. 2020. URL: http://www.palauhealth.org/ [accessed 2020-08-14]

87. COVID-19 Pandemic. Ministry of Health - Papua New Guinea. 2020. URL: https://www.health.gov.pg/subindex.php?news=1 [accessed 2020-08-14]

88. COVID-19 Tracker. Republic of the Philippines Department of Health. 2020. URL: https://www.doh.gov.ph/covid19tracker [accessed 2020-08-14]

89. Novel Coronavirus (COVID-19). Government of Samoa. 2020. URL: https://www.samoagovt.ws/category/ novel-coronavirus-covid-19/ [accessed 2020-08-14]

90. Learn about Coronavirus. Solomon Islands Government. 2020. URL: https://solomons.gov.sb/ ministry-of-health-medical-services/essential-services/learn-about-coronavirus/ [accessed 2020-08-14]

91. Updates on COVID-19 (Coronavirus Disease 2019) Local Situation. Ministry of Health of Singapore. 2020. URL: https:/ /www.moh.gov.sg/covid-19 [accessed 2020-08-14]

92. Coronavirus Disease (COVID-19). Thailand Department of Disease Control. 2020. URL: https://ddc.moph.go.th/ viralpneumonia/eng/index.php [accessed 2020-08-14]

93. COVID-19 Updates. Vanuatu Ministry of Health. 2020. URL: https://covid19.gov.vu/ [accessed 2020-08-14]

94. Oehmke J, Moss C, Singh L, Oehmke T, Post L. Dynamic Panel Surveillance of COVID-19 Transmission in the United States to Inform Health Policy: Observational Statistical Study. J Med Internet Res 2020 Oct 5;22(10):e21955 [FREE Full text] [doi: 10.2196/21955] [Medline: 32924962]

95. Ibrahim NK. Epidemiologic surveillance for controlling Covid-19 pandemic: types, challenges and implications. J Infect Public Health 2020 Nov;13(11):1630-1638 [FREE Full text] [doi: 10.1016/j.jiph.2020.07.019] [Medline: $\underline{32855090]}$

96. Oehmke JF, Oehmke TB, Singh LN, Post LA. Dynamic Panel Estimate-Based Health Surveillance of SARS-CoV-2 Infection Rates to Inform Public Health Policy: Model Development and Validation. J Med Internet Res 2020 Sep 22;22(9):e20924 [FREE Full text] [doi: 10.2196/20924] [Medline: 32915762]

97. Foddai A, Lubroth J, Ellis-Iversen J. Base protocol for real time active random surveillance of coronavirus disease (COVID-19) - Adapting veterinary methodology to public health. One Health 2020 Jun;9:100129 [FREE Full text] [doi: 10.1016/j.onehlt.2020.100129] [Medline: $\underline{\text { 32292815] }}$

98. Dong E, Du H, Gardner L. An interactive web-based dashboard to track COVID-19 in real time. The Lancet Infectious Diseases 2020 May;20(5):533-534. [doi: 10.1016/s1473-3099(20)30120-1]

99. Lin Y, Liu C, Chiu Y. Google searches for the keywords of "wash hands" predict the speed of national spread of COVID-19 outbreak among 21 countries. Brain Behav Immun 2020 Jul;87:30-32 [FREE Full text] [doi: 10.1016/j.bbi.2020.04.020] [Medline: $\underline{32283286}$ ]

100. Sajadi MM, Habibzadeh P, Vintzileos A, Shokouhi S, Miralles-Wilhelm F, Amoroso A. Temperature, Humidity and Latitude Analysis to Predict Potential Spread and Seasonality for COVID-19. SSRN Journal Preprint posted online Mar 9, 2020. [doi: 10.2139/ssrn.3550308] [Medline: 32714105]

101. Binti Hamzah FA, Lau C, Nazri H, Ligot DV, Lee G, Tan GL. CoronaTracker: Worldwide COVID-19 Outbreak Data Analysis and Prediction. Bulletin of the World Health Organization 2020 Mar 19:1-32. [doi: 10.2471/BLT.20.255695]

102. Petropoulos F, Makridakis S. Forecasting the novel coronavirus COVID-19. PLoS One 2020 Mar 31;15(3):e0231236 [FREE Full text] [doi: 10.1371/journal.pone.0231236] [Medline: 32231392]

103. Thacker SB, Berkelman RL. Public health surveillance in the United States. Epidemiol Rev 1988;10:164-190. [doi: 10.1093/oxfordjournals.epirev.a036021] [Medline: 3066626]

104. Lee L, Teutsch S, Tacker S, St. Louis M. Considerations in planning a surveillance system. In: Principles and Practice of Public Health Surveillance. Oxford, UK: Oxford Scholarship Online; 2010:18-28. 
105. Day M. Covid-19: four fifths of cases are asymptomatic, China figures indicate. BMJ 2020 Apr 02;369:m1375. [doi: 10.1136/bmj.m1375] [Medline: 32241884]

106. He J, Guo Y, Mao R, Zhang J. Proportion of asymptomatic coronavirus disease 2019: A systematic review and meta-analysis. J Med Virol 2021 Feb 13;93(2):820-830 [FREE Full text] [doi: 10.1002/jmv.26326] [Medline: 32691881]

107. Al-Sadeq DW, Nasrallah GK. The incidence of the novel coronavirus SARS-CoV-2 among asymptomatic patients: A systematic review. Int J Infect Dis 2020 Sep;98:372-380 [FREE Full text] [doi: 10.1016/j.ijid.2020.06.098] [Medline: 32623083]

108. An P, Song P, Wang Y, Liu B. Asymptomatic Patients with Novel Coronavirus Disease (COVID-19). Balkan Med J 2020 Jun 01;37(4):229-230 [FREE Full text] [doi: 10.4274/balkanmedj.galenos.2020.2020.4.20] [Medline: 32279479]

109. Lipton Z, Riley K. The Covid Tracking Project. The Atlantic. 2020. URL: https://covidtracking.com/ [accessed 2020-10-19]

110. Roser M, Ortiz-Ospina E, Hassell J. Coronavirus Pandemic (COVID-19). Our World in Data. 2020. URL: https:/ lourworldindata.org/coronavirus [accessed 2020-10-13]

111. FINDCov19TrackerData. The Foundation for Innovative New Diagnostics. 2020. URL: https://www.finddx.org/covid-19/ test-tracker/ [accessed 2020-10-13]

112. Brownstein JS, Freifeld CC, Madoff LC. Digital Disease Detection - Harnessing the Web for Public Health Surveillance. N Engl J Med 2009 May 21;360(21):2153-2157. [doi: 10.1056/nejmp0900702]

113. The Covid Tracking Project. GitHub. 2020. URL: https://github.com/COVID19Tracking [accessed 2020-10-19]

114. FINDCov19TrackerData. GitHub. 2020. URL: https://github.com/dsbbfinddx/FINDCov19TrackerData [accessed 2020-10-19]

115. COVID-19 Data Repository by their for Systems Science and Engineering (CSSE) at Johns Hopkins University. GitHub. 2020. URL: https://github.com/CSSEGISandData/COVID-19 [accessed 2020-10-19]

116. Hansen LP. Large Sample Properties of Generalized Method of Moments Estimators. Econometrica 1982 Jul;50(4):1029. [doi: $10.2307 / 1912775$ ]

117. Post L. Global SARS-CoV-2 Surveillance:Policy, Persistence, Transmission-East Asia and Pacific. 2020 Oct 25. URL: https://public.tableau.com/profile/lori.post\#!/vizhome/

GlobalSARS-CoV-2SurveillancePolicyPersistenceandTransmission-EastAsiaandPacific/Story [accessed 2020-10-25]
Abbreviations
BCG: Bacille Calmette-Guérin
GDP: gross domestic product
GMM: generalized method of moments
KCDC: Korean Centers for Disease Control
MERS: Middle East respiratory syndrome
SARS: severe acute respiratory syndrome
WHO: World Health Organization

\author{
Edited by $G$ Eysenbach; submitted 09.11.20; peer-reviewed by $P$ Banik; comments to author 30.11.20; revised version received \\ 30.11.20; accepted 16.01.21; published 01.02.21 \\ Please cite as: \\ Post LA, Lin JS, Moss CB, Murphy RL, Ison MG, Achenbach CJ, Resnick D, Singh LN, White J, Boctor MJ, Welch SB, Oehmke JF \\ SARS-CoV-2 Wave Two Surveillance in East Asia and the Pacific: Longitudinal Trend Analysis \\ J Med Internet Res 2021;23(2):e25454 \\ URL: https://www.jmir.org/2021/2/e25454 \\ doi: $\underline{10.2196 / 25454}$ \\ PMID: 33464207
}

CLori Ann Post, Jasmine S Lin, Charles B Moss, Robert Leo Murphy, Michael G Ison, Chad J Achenbach, Danielle Resnick, Lauren Nadya Singh, Janine White, Michael J Boctor, Sarah B Welch, James Francis Oehmke. Originally published in the Journal of Medical Internet Research (http://www.jmir.org), 01.02.2021. This is an open-access article distributed under the terms of the Creative Commons Attribution License (https://creativecommons.org/licenses/by/4.0/), which permits unrestricted use, distribution, and reproduction in any medium, provided the original work, first published in the Journal of Medical Internet Research, is properly cited. The complete bibliographic information, a link to the original publication on http://www.jmir.org/, as well as this copyright and license information must be included. 